Bulletin UASVM Food Science and Technology 70(2)/2013, 124-128

ISSN-L 2344-2344; Print ISSN 2344-2344; Electronic ISSN 2344-5300

\title{
Minerals Concentration and Textural Properties of Romanian Beef Row and Cooked Meat and Offal
}

\section{Liliana TUDOREANU ${ }^{1)}$, Gheorghe Valentin GORAN ${ }^{2)}$, Victor CRIVINEANU $^{3)}$, Darius Mario CODREANU ${ }^{4)}$}

\author{
${ }^{1)}$ Interdisciplinary Laboratory for Heavy Metals Accumulation in the Food Chain and Modelling \\ (HEVMETFOOD); University of Agronomic Sciences and Veterinary Medicine Bucharest, Splaiul \\ Independenţei nr 105, Bucharest Romania; \\ liliana_tudoreanu223@hotmail.co.uk
}

\begin{abstract}
Consumers preferences for solid food are, for the majority of foods groups, influenced by their textural properties. Romanian traditional cuisine is rich in meat foods and therefore this food group has an important contribution to the total mineral intake as well as the ingestion of potentially toxic metals such as $\mathrm{Cd}$ and $\mathrm{Pb}$.

Although beef liver is an important source of minerals for human consumption, its concentrations in $\mathrm{Cd}$ and $\mathrm{Pb}$ and heterogeneous textural properties may hinder its acceptability.

The purpose of the work was to estimate raw and cooked beef meat and offal mineral quality including $\mathrm{Cd}$ and $\mathrm{Pb}$ concentrations and their contribution to a balanced human diet and health as well as the influenced of thermal preparation on their mineral and textural properties.

Beef liver, kidney and longissimus dorsi muscle were bought from local markets. Thermal preparation was conducted by microwave and boiling with no water contact. Texture profile analyses was conducted for quantifying textural properties such as Hardness, Cohesiveness, Springiness, Springiness Index, Chewiness, Adhesiveness and Stiffness. The mineral concentrations of the raw and cooked samples were analyzed by ICP-MS.

The offal textural parameters variability was very large within the same organ and compared to the muscle textural parameters variability too. Muscle and offal thermal preparation strongly influenced their minerals' concentrations as well as their textural properties. Thermal preparation significantly decreased beef liver and kidney samples' total $\mathrm{K}$ and Na concentrations. It is suggested that for improving beef liver acceptability, the consumer has to be advised on the influence of the thermal preparation on beef liver parts' textural properties as well as minerals concentrations.
\end{abstract}

Keywords: beef, offal, textural properties, minerals, $\mathrm{Cd}, \mathrm{Pb}$

\section{INTRODUCTION}

A few studies reported the influence of potentially toxic metals such as $\mathrm{Cd}, \mathrm{Pb}$ on the levels of essential metals such as $\mathrm{Cu}, \mathrm{Zn}, \mathrm{Fe}, \mathrm{Mn}$ in cattle from industrialized areas (Miranda et. al., 2005; Püssa, 2013; Roggeman et al, 2014 available on line in 2013; Sedki et al, 2003).

Roggeman et al (2014, available on line in 2013) investigated the total concentrations of $\mathrm{Cd}$ and $\mathrm{Pb}$ in liver, kidney and muscle as well as $\mathrm{Ag}, \mathrm{Cd}, \mathrm{Pb}, \mathrm{Al}, \mathrm{Cr}, \mathrm{Mn}, \mathrm{Fe}, \mathrm{Co}, \mathrm{Ni}, \mathrm{Cu}$, and $\mathrm{Zn}$ of dairy cows from a polluted area in Belgium. They reported that $\mathrm{Cd}$ and $\mathrm{Pb}$ levels exceeded the European limits for human consumption for $40 \%$ of the livers and $85 \%$ of the kidneys of all examined cows. However the levels of $\mathrm{Cd}$ and $\mathrm{Pb}$ in muscle samples did not exceed the European limits for human consumption. They also suggested that, taking into consideration the minimum 
risk levels (MRLs) for chronic oral exposure for $\mathrm{Cr}$, the local population consuming local beef is at risk for chronic $\mathrm{Cr}$ oral exposure. They recommended that a person of $70 \mathrm{~kg}$ should not eat more than $150 \mathrm{~g}$ beef meat per day because of the existing $\mathrm{Cr}$ levels in the muscles. However the recommendations they made did not take into account the possible increase of total $\mathrm{Cd}$ and $\mathrm{Pb}$ concentrations in beef meat and offal due to thermal preparation.

No studies were found on texture of beef raw and cooked kidney, liver and muscle in and the influence of texture on the level of consumption.

We believe that textural properties of cooked beef muscle and offal may influence the quantity of this foods type in the diet.

Aims and objectives. The research aim was to investigate the contribution of beef offal and muscle to mineral balance in the human diet and to $\mathrm{Cd}$ and $\mathrm{Pb}$ ingestion.

The major objectives were:

a) to estimate the total concentrations of $\mathrm{Al}, \mathrm{Ca}, \mathrm{Cd}, \mathrm{Co}, \mathrm{Cr}, \mathrm{Cu}, \mathrm{Fe}, \mathrm{K}, \mathrm{Mg}, \mathrm{Mn}, \mathrm{Na}, \mathrm{Pb}$, and $\mathrm{Zn}$ in raw and cooked beef muscle, kidney and liver from cows breaded in an industrial area of Romania;

b) to estimate the textural properties of raw and cooked beef muscle, kidney and liver; c) to estimate the implication of thermal preparation on mineral content and textural properties of raw and cooked beef muscle and offal.

\section{MATERIALS AND METHODS}

The samples were collected from the local market in the industrial region of Slatina, Romania.

Mineral analyses were performed by ICP-MS using a Thermo X Series 2 according to Note 5-Clinical Applications-Thermo Electron Corporation, the samples digestion was conducted according to the methods described by Tonilo et al. (2009).

The organs and muscle were cut into $2 \mathrm{~cm} \times 2 \mathrm{~cm} \times 2 \mathrm{~cm}$ samples and one third (60 samples) of all samples was cooked for $8 \mathrm{~min}$ in a cooking plastic bag, using a microwave oven at $600 \mathrm{~W}$.

The second third was cooked in cooking plastic bags at in boiling water $\left(100^{\circ} \mathrm{C}\right)$; the samples were not in contact with the water.

The rest of the samples were analyzed in raw state. Texture profile analyses were performed using the Universal Texture Analyzer TA-PLUS and the NEXIGEN software (Lloyd Company).

The textural properties which were analyzed are presented in Tab. 1. The texture probes used were the parallel plates (TPA).

\section{RESULTS AND DISCUSSIONS}

Textural properties of the cooked offal and meat are presented in Table 1. The total minerals concentrations in cooked offal are presented in Table 2.

The thermal preparation (Table 2) showed a significant increase in minerals for cooked offal except for the $\mathrm{Na}$ and $\mathrm{K}$. 
Tab. 1

Beef offal textural properties mean values and standard deviations

\begin{tabular}{|l|c|l|c|c|}
\hline \multirow{2}{*}{ Textural properties } & \multicolumn{4}{|c|}{ TPA 80\% } \\
\cline { 2 - 5 } & \multicolumn{2}{|c|}{ Beef liver } & \multicolumn{2}{c|}{ Beef Kidney } \\
\cline { 2 - 5 } & Boiled 100C & Micro-wave & Boiled 100C & Micro-wave \\
\hline Hardness (N) & $227.7 \pm 75.60$ & $267.89 \pm 160.46$ & $318.6 \pm 144.55$ & $236.29 \pm 127.98$ \\
\hline Cohesiveness & $0.20 \pm 0.06$ & $0.10 \pm 0.065$ & $0.25 \pm 0.09$ & $0.36 \pm 0.07$ \\
\hline Springiness (mm) & $10.19 \pm 3.49$ & $6.77 \pm 3.24$ & $11.44 \pm 2.66$ & $10.32 \pm 2.08$ \\
\hline Springiness Index & $0.67 \pm 0.21$ & $0.50 \pm 0.25$ & $0.74 \pm 0.13$ & $0.80 \pm 0.08$ \\
\hline Chewiness (Nmm) & $443.69 \pm 221.33$ & $241.23 \pm 270.51$ & $829.25 \pm 439.95$ & $841.87 \pm 421.56$ \\
\hline Fracture Force (N) & $180.99 \pm 74.40$ & $194.63 \pm 131.60$ & $284.00 \pm 162.65$ & $205.65 \pm 117.56$ \\
\hline Adhesive Force (N) & $0.06 \pm 0.13$ & $1.07 \pm 1.40$ & $0.05 \pm 0.04$ & $0.21 \pm 0.24$ \\
\hline Adhesiveness (N mm) & $0.06 \pm 0.01$ & $0.93 \pm 2.37$ & $0.04 \pm 0.11$ & $0.489 \pm 0.88$ \\
\hline Stiffness (N/mm) & $104.08 \pm 89.80$ & $117.48 \pm 64.80$ & $124.71 \pm 58.25$ & $110.51 \pm 47.24$ \\
\hline
\end{tabular}

The total $\mathrm{Cd}$ and $\mathrm{Pb}$ concentration in the raw liver were $3.61 \mathrm{ppm}$ and $6.39 \mathrm{ppm}$ wet weight respectively. The microwave cooking method increases liver hardness however kidney hardness decrease compared to the boiling method.

The data of the present study are consistent with the data on beef offal communicated by Miranda et al. (2005), who found $29.6 \mathrm{ppm}$ wet weight for total liver Cd concentration and 38.1ppm wet weight for the total $\mathrm{Pb}$ liver concentration.

Total $\mathrm{Cd}$ concentration in kidneys was of $161 \mathrm{ppm}$ wet weight and the total $\mathrm{Pb}$ concentration was of 38.3 ppm wet weight. 
Tab. 2

Minerals concentrations and standard deviations in beef offal

\begin{tabular}{|l|l|l|r|r|}
\hline \multirow{2}{*}{ Mineral } & \multicolumn{4}{|c|}{ Wet weight, ppm } \\
\cline { 2 - 5 } & \multicolumn{2}{|c}{ Beef liver } & \multicolumn{2}{c|}{ Beef kidney } \\
\cline { 2 - 5 } & Micro-wave & Boiled 100C & \multicolumn{1}{c|}{ Micro-wave } & \multicolumn{1}{c|}{ Boiled } \\
\hline $\mathrm{Al}$ & $10.5 \pm 0.01$ & $9.71 \pm 0.01$ & $1.91 \pm 0.01$ & $1.64 \pm 0.01$ \\
\hline $\mathrm{Ca}$ & $26.33 \pm 0.03$ & $18.74 \pm 0.03$ & $8.37 \pm 0.02$ & $7.65 \pm 0.02$ \\
\hline $\mathrm{Cd}$ & $5.11 \pm 0.01$ & $3.72 \pm 0.01$ & $0.973 \pm 0.001$ & $0.836 \pm 0.001$ \\
\hline $\mathrm{Co}$ & $3.61 \pm 0.01$ & $2.37 \pm 0.01$ & $1.46 \pm 0.01$ & $1.05 \pm 0.01$ \\
\hline $\mathrm{Cr}$ & $4.31 \pm 0.01$ & $3.1 \pm 0.01$ & $0.928 \pm 0.001$ & $0.779 \pm 0.001$ \\
\hline $\mathrm{Cu}$ & $8.24 \pm 0.02$ & $6.88 \pm 0.02$ & $2.25 \pm 0.01$ & $1.96 \pm 0.01$ \\
\hline $\mathrm{Fe}$ & $13.28 \pm 0.02$ & $13.24 \pm 0.02$ & $8.51 \pm 0.01$ & $2.98 \pm 0.01$ \\
\hline $\mathrm{K}$ & $248.29 \pm 0.02$ & $268.67 \pm 0.02$ & $86.8 \pm 0.02$ & $89.76 \pm 0.02$ \\
\hline $\mathrm{Mg}$ & $18.73 \pm 0.02$ & $18.52 \pm 0.02$ & $8.47 \pm 0.01$ & $8.192 \pm 0.01$ \\
\hline $\mathrm{Mn}$ & $3.19 \pm 0.01$ & $2.19 \pm 0.01$ & $0.753 \pm 0.001$ & $0.619 \pm 0.001$ \\
\hline $\mathrm{Na}$ & $34.82 \pm 0.03$ & $40.75 \pm 0.03$ & $86.88 \pm 0.02$ & $29.48 \pm 0.02$ \\
\hline $\mathrm{Ni}$ & $5.03 \pm 0.01$ & $3.77 \pm 0.01$ & $1.43 \pm 0.01$ & $1.12 \pm 0.01$ \\
\hline $\mathrm{Pb}$ & $8.00 \pm 0.02$ & $6.57 \pm 0.02$ & $1.83 \pm 0.01$ & $1.47 \pm 0.01$ \\
\hline $\mathrm{Sr}$ & $4.33 \pm 0.02$ & $3.29 \pm 0.02$ & $1.262 \pm 0.001$ & $0.963 \pm 0.001$ \\
\hline $\mathrm{Zn}$ & $5.15 \pm 0.01$ & $4.21 \pm 0.01$ & $1.82 \pm 0.01$ & $1.5 \pm 0.01$ \\
\hline
\end{tabular}

\section{CONCLUSION}

1. Thermal preparation of meet and offal will increase all minerals concentration in beef meet and offal, except for $\mathrm{Na}$ and $\mathrm{K}$ which will decrease.

2. $\mathrm{Cd}$ and $\mathrm{Pb}$ concentrations in offal were above the European limit for human consumption; however in muscle samples they did not exceed the minimum risk level for chronic oral exposure.

3. The concentration of $\mathrm{Cd}$ and $\mathrm{Pb}$ in offal and muscle will increase after cooking due to water loss from the tissues, and will be influenced by the thermal preparation method.

4. Raw and cooked offal textural properties values are highly heterogeneous within the same organ; the textural properties of cooked offal and muscle were depended of the cooking method.

5. It is suggested that for improving offal and muscle acceptability, the consumer has to be advised on the influence of thermal preparation on their textural properties as well as on the minerals concentrations after cooking.

6. Our study suggests that for offal the quantity which should be recommended for daily total intake for a $70 \mathrm{Kg}$ person should take into consideration the concentrations after thermal preparation, and the influence of the thermal preparation method on the total concentration of potentially toxic minerals. 


\section{REFERENCES}

1. Miranda, M., López-Alonso M., Castillo C., Hernández, J., and Benedito, (2005). Effects of moderate pollution on toxic and trace metal levels in calves from a polluted area of northern Spain. Environment International: 31 (4), 543-548.

2. Roggeman, S., de Boeck G., De Cock H., Blust, R. and Bervoets L. (2014). Accumulation and detoxification of metals and arsenic in tissues of cattle (Bos Taurus), and the risks for human consumption. Science of The Total Environment: 466-467, 175-184. http://www.sciencedirect.com/science/article/pii/S0048969713007754 (available on-line in 2013).

3. Püssa, T., (2013). Toxicological issues associated with production and processing of meat. Meat Science: 95 (4), 844-853

4. Sedki, A., Lekouch, N., Gamon, S., and Pineau, A. (2003).Toxic and essential trace metals in muscle, liver and kidney of bovines from a polluted area of Morocco. Science of The Total Environment: 317 (1-3), 201-205

5. Toniolo, R.,Tubaro, F., Bin, S., Pizzariello, A., Susmel, S., Dossi, N., and Bontempelli, G. (2009) Single-step microwave digestion of food and biological samples for the quantitative conversion of Se into the +4 oxidation state. Talanta $78753-758$.

6. *** Determination of Cadmium and Lead by ICP-MS. CLG-TM3.01 of United States Department of Agriculture Food Safety and Inspection Service, Office of Public Health Science Samples.

7. *** Clinical Applications. Note 5: Trace element quantification in blood and serum in a single analytical run. X Series ICP-MS. Thermo Electron Corporation. 